\title{
Thyroxine Inner Ring Monodeiodinating Activity in Fetal Tissues of the Rat
}

\author{
TIEN-SHANG HUANG, INDER J. CHOPRA, RUBEN BOADO, DAVID H. SOLOMON, AND \\ GUADALUPE N. CHUA TECO \\ Department,of.Medicine, UCLA Center for the Health Sciences, Los Angeles, California 90024
}

\begin{abstract}
We studied thyroxine $\left(\mathrm{T}_{4}\right)$ inner ring monodeiodinating activity (5-MA) in various tissues of fetal, maternal, and adult male rats. Tissue homogenates were incubated with $0.26 \mu \mathrm{M} \mathrm{T}_{4}$ in $0.1 \mathrm{M}$ phosphate buffer (pH 7.4) containing $10 \mathrm{mM}$ EDTA and $400 \mathrm{mM}$ dithiothreitol (final volume $0.7 \mathrm{ml}$ ) for $10 \mathrm{~min}$ at $37^{\circ} \mathrm{C}$; the $3,3^{\prime}, 5^{\prime}-$ triiodothyronine $\left(\mathrm{rT}_{3}\right)$ generated was measured by radioimmunoassay of ethanol extracts of incubation mixture and the result was corrected for $\mathbf{r T}_{3}$ degradation during incubation. Compared to maternal tissues, $\mathrm{T}_{4}$ to $\mathrm{rT}_{3} 5-\mathrm{MA}$ in the 14-day-old fetus was increased about 70 times in skeletal muscle (mean \pm SEM, velocity, $5.4 \pm 0.9$ versus 0.08

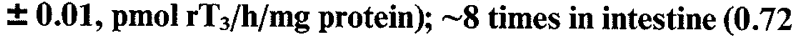
\pm 0.17 versus $0.09 \pm 0.03)$; and $\sim 4$ times in cerebral cortex (19 \pm 0.5 versus $4.5 \pm 0.9$ ), while it was similar in skin (3.2 \pm 0.48 versus $2.6 \pm 0.52$ ). Hepatic $T_{4} 5$-MA approximated $1.1 \pm 0.63$ in the 14-day-old fetus; it could not be measured reliably in maternal or 19-day fetal tissue because of extensive ( $>90 \%$ ) degradation of $\mathrm{rT}_{3}$ during incubation. Relative to mother, $T_{4}$ 5-MA in 19-day fetal tissues was increased $\sim 30$-fold in intestine, $\sim 20$-fold in skeletal muscle, and $\sim 6$-fold in cerebral cortex while it was similar in skin. The $T_{4}$ 5-MA in maternal rat tissues did not differ significantly from corresponding values in adult male rat, except skin, where it was lower in the mother rat ( $2.6 \pm 0.52$ versus $4.6 \pm 0.61, p<0.05$ ). In summary, relative to adult tissues $\mathrm{T}_{4} 5$-MA is exceedingly active in several fetal tissues, most notably in skeletal muscle followed by intestine and cerebral cortex. (Pediatr Res 23: 196-199, 1988)
\end{abstract}

\section{Abbreviations}

$T_{4}$, thyroxine

$\mathbf{r T}_{3}, \mathbf{3}, \mathbf{3}^{\prime}, \mathbf{5}^{\prime}$-triiodothyronine

$T_{3}, 3,5,3^{\prime}$-triiodothyronine

5-MA, iodothyronine inner ring monodeiodinating activity $5^{\prime}$-MA, iodothyronine outer ring monodeiodinating activity MA, iodothyronine $5^{\prime}$-monodeiodinase activity

DTT, dithiothreiotol

$3,3^{\prime}-T_{2}, 3,3^{\prime}$-diiodothyronine

RIA, radioimmunoassay

Vmax, maximal velocity

Previous studies $(1,2)$ have demonstrated that the fetal hypothalamo-pituitary-thyroid system develops and functions inde-

Received August 3, 1987; accepted October 8, 1987.

Supported by USPHS Grant AM16155 from the National Institute of Health, Bethesda, MD.

Reprint requests Inder J. Chopra, M.D., Department of Medicine, UCLA Center for the Health Sciences, Los Angeles, CA 90024. pendently of the maternal system. Fetal tissues, e.g. liver, also show in some species an age-related, progressive increase in $5^{\prime}$ MA accompanied by a reciprocal decrease in 5-MA (3). The pituitary-thyroid axis and tissue metabolism of iodothyronines both begin maturation toward adult levels in the last third of gestation in several species including man, sheep, and chicken (3-5) but not in the rat where maturation occurs in the immediate postnatal period $(6,7)$. The maturation pattern of tissue 5 -MA has been studied in several tissues, including liver, pituitary gland, kidney, cerebrum, cerebellum, and hypothalamus in several species (8-13). However, there is a paucity of information regarding the maturation of 5-MA in fetal tissues. 5-MA has been observed to be very active in the placenta (14) and in some neuronal tissues of the fetal rat, e.g. the cerebrum and the hypothalamus $(10,15,16)$. Compared to body fluids of the adult, the concentration of $\mathrm{rT}_{3}$ is much higher in fetal serum and amniotic fluid $(12,17)$. To gather insight into the contribution of the various fetal organs to the high $\mathrm{rT}_{3}$ in fetal serum and amniotic fluid, we have studied $\mathrm{T}_{3} 5$-MA in various tissues. This information may be important in understanding physiological role of $\mathrm{rT}_{3}$ either as $\mathrm{rT}_{3}$ per se or as a route to metabolism of $\mathrm{T}_{4}$ to inactive metabolites. Our data suggest that the $\mathrm{T}_{4} 5-\mathrm{MA}$ is higher in several fetal tissues than in adult tissues, but most notably in skeletal muscle and the intestine.

\section{MATERIALS AND METHODS}

Animal tissues. Timed pregnant Sprague-Dawley rats were obtained from Charles River Breeding Laboratories, Inc., Boston, MA. Fourteen or 19 day pregnant Sprague-Dawley rats (pregnancy in rat approximates 21 days) were anesthetized with ether and fetuses were removed from the uterus. Various organs of mothers and fetuses were dissected and homogenized in cold assay buffer (w/v, 10-33\%) using a polytron homogenizer (Brinkman Instruments, Westbury, NY). Skeletal muscle tissues used were dissected predominantly from the thigh and the leg. Intestinal and dermal tissues were studied without separation into individual components (e.g. epithelium versus muscle in intestine or epidermis versus dermis in skin).

Reagents. $\mathrm{T}_{4}$ and DTT were obtained from Sigma Chemical Co., St. Louis, MO. $\mathrm{rT}_{3}$ and 3,3'-T were obtained through the courtesy of Dr. Paul Block, Jr., of River Research, Toledo, OH. Radioactive $\mathrm{T}_{4}$ and $\mathrm{rT}_{3}$ were obtained from New England $\mathrm{Nu}$ clear, Boston, MA.

Study of $T_{4}$ to $r T_{3} M A$. Homogenates of various tissues ( 3 to $13 \mathrm{mg}$ protein) were incubated in duplicate with $0.26 \mu \mathrm{M}(200$ $\mathrm{ng} / \mathrm{ml}$ ) $\mathrm{T}_{4}$ in $0.1 \mathrm{M}$ phosphate buffer (pH 7.4) containing 10 $\mathrm{mM}$ EDTA and $400 \mathrm{mM}$ DTT (total volume, $0.7 \mathrm{ml}$ ) for $10 \mathrm{~min}$ at $37^{\circ} \mathrm{C}$; the $\mathrm{rT}_{3}$ generated was measured by RIA of ethanol extracts of incubation mixture as previously described $(15,18$, 19). $T_{4}$ cross-reated $0.06 \%$ in $\mathrm{rT}_{3}$ RIA. The intrassay and interassay coefficient of variation for $\mathrm{rT}_{3}$ measurement was 6 and $9 \%$, respectively. Protein concentration was measured by the 
method of Bradford (20). Previous studies with adult cerebral cortical and skin tissues $(15,19)$ and pilot studies with fetal skeletal muscle tissues had shown that $\mathrm{T}_{4}$ to $\mathrm{rT}_{3}$ conversion was near maximal under the above mentioned conditions. The results of $\mathrm{T}_{4}$ 5-MA were expressed as pmol of $\mathrm{rT}_{3}$ produced per $\mathrm{h} / \mathrm{mg}$ protein after correction for $\mathrm{rT}_{3}$ degradation during the incubation. The latter correction was made by dividing $\mathrm{rT}_{3}$ produced during incubation with (100\% minus degradation of $\mathrm{rT}_{3}$ during incubation studied as described below).

In some experiments, $\mathrm{Km}$ and $\mathrm{Vmax}$ of $\mathrm{T}_{4}$ 5-MA were measured in certain tissues. For this purpose, maternal or pooled fetal tissue aliquots were incubated for $30 \mathrm{~min}$ at $37^{\circ} \mathrm{C}$ with 0.04 to $2.5 \mu \mathrm{M} \mathrm{T}_{4}$ in the presence of $400 \mathrm{mM}$ DTT and $\mathrm{rT}_{3}$ produced during incubation was measured by the RIA. The results of $\mathrm{rT}_{3}$ generated during incubation were corrected for degradation of $\mathrm{rT}_{3}$ during incubation and the data on $\mathrm{T}_{4} 5-\mathrm{MA}$ were computed in terms of pmol of $\mathrm{rT}_{3}$ produced per $\mathrm{h} / \mathrm{mg}$ protein. $\mathrm{Km}$ and Vmax were calculated from the Lineweaver-Burk plot of the data after the data had been subjected to linear regression analysis by the method of least mean squares $(21,22)$.

Degradation of $r T_{3}$ during incubation. When $\mathrm{rT}_{3}$ degradation was to be studied, the tissue homogenates were incubated as described above, with $7.7,15$, or $30 \mathrm{pmol} \mathrm{rT}_{3}$ and the percent $\mathrm{rT}_{3}$ remaining at the end of incubation was determined by RIA. Percent degradation of each amount of $\mathrm{rT}_{3}$ added was calculated and the results were expressed as an average of various determinations for each tissue. Pilot studies had shown that $\mathrm{rT}_{3}$ was degraded by various tissues mainly by $5^{\prime}$-monodeiodination to 3,3'-diiodothyronine.

Other statistical analyses. The data on $\mathrm{rT}_{3}$ degradation or $\mathrm{T}_{4}$ 5-MA in different groups were reduced to the mean \pm SEM and the results were compared using Student's two tailed $t$ test for unpaired variates. For some studies, Bonferroni's correction for multiple comparisons was applied to the $t$ test (22).

\section{RESULTS}

Table 1 shows the results of $\mathrm{rT}_{3}$ degradation in maternal, adult male, and fetal tissues. Maternal and adult male rat liver degraded
$\mathrm{rT}_{3}$ very actively; approximately $90 \%$ of $\mathrm{rT}_{3}$ was lost during a 10 -min incubation. Other tissues of the adult rat degraded $\mathrm{rT}_{3}$ modestly. The degradation of $\mathrm{rT}_{3}$ approximated $\sim 5 \%$ for intestine, $\sim 10 \%$ for skeletal muscle, and $<5 \%$ for cerebral cortex and skin. Fourteen-day-old fetal liver degraded only about $20 \%$ of substrate $\mathrm{rT}_{3}$ during the 10-min incubation, whereas 19-day-old fetal liver degraded $\mathrm{rT}_{3}$ as actively as did adult tissue. Fetal intestine degraded $\sim 12 \% \mathrm{rT}_{3}$ at 14 -day gestation and $\sim 29 \%$ at 19-day gestation. Fetal skeletal muscle demonstrated a moderate $\sim 11 \%$ degradation of $\mathrm{rT}_{3}$ at 14-day gestation but little $(<5 \%)$ degradation at 19-day gestation. The cerebral cortical or skin tissues of adult and fetal rat demonstrated less than 5\% degradation of $\mathrm{rT}_{3}$ for up to $1 \mathrm{~h}$ of incubation.

Table 2 shows the data on $\mathrm{T}_{4} 5-\mathrm{MA}$ in various tissues of maternal and fetal (14 and 19 day old) rats after correction for $\mathrm{rT}_{3}$ degradation during incubation. Fetal skeletal muscle, intestine, and cerebral cortex demonstrated more active $\mathrm{T}_{4} 5-\mathrm{MA}$ than the corresponding maternal tissues, even when Bonferroni's correction for multiple comparisons was applied to the $t$ test. Skeletal muscle showed the largest $(\sim 70$-fold $)$ increase at 14-day gestation and intestine showing the largest $(\sim 30$-fold $)$ increase at 19-day gestation. Skin $\mathrm{T}_{4}$ 5-MA was similar in the fetus and the mother. Fetal hepatic $\mathrm{T}_{4} 5-\mathrm{MA}$ of $1.1 \pm 0.63 \mathrm{pmol} / \mathrm{h} / \mathrm{mg}$ protein at 14-day gestation was similar to or lower than that in other fetal tissues of comparable gestation. Hepatic $\mathrm{T}_{4}$ 5-MA in 19day-old fetal, maternal, and adult rat was computed to be $15 \pm$ $4.6,20 \pm 6.8$, and $17 \pm 5.1 \mathrm{pmol} / \mathrm{h} / \mathrm{mg}$ protein, respectively. However, the reliability of these values is uncertain. These liver tissues degraded $\mathrm{rT}_{3}$ extensively during incubation (90-94\%) (Table 1) and this factor necessitated a very large correction in the calculation of $\mathrm{T}_{4} 5-\mathrm{MA}$ in terms of $\mathrm{rT}_{3}$ produced per $\mathrm{h} / \mathrm{mg}$ protein. $\mathrm{T}_{4} 5$-MA in maternal skin was lower than that in the adult male skin $(p<0.05)$. $\mathrm{T}_{4} 5-\mathrm{MA}$ in other maternal tissues studied was comparable to that in tissues of the adult male rat. Similar results were obtained in another experiment using 10min incubation and two other experiments using incubation of $1 \mathrm{~h}$ instead of $10 \mathrm{~min}$.

The $\mathrm{Km}$ and $V \max$ of fetal skeletal muscle $\mathrm{T}_{4} 5$-MA were measured at 14-day gestation and approximated $0.66 \mu \mathrm{M}$ and $5.0 \mathrm{pmol} / \mathrm{h} / \mathrm{mg}$ protein, respectively. The reaction rate for $\mathrm{T}_{4}$ to

Table 1. Degradation of $r T_{3}$ during incubation for $10 \mathrm{~min}$ with homogenates of tissues of maternal, fetal, and adult male rats

\begin{tabular}{lccccc}
\hline & & \multicolumn{4}{c}{ Tissue (\% of added rT3 degraded) } \\
\cline { 2 - 5 } Group & Cerebral cortex & Skin & Intestine & Skeletal muscle & Liver \\
\hline Mother & $\mathrm{n} \dagger$ & $\mathrm{n}$ & $5.0 \pm 3.0^{*}$ & $10 \pm 3.8$ & $94 \pm 1.5$ \\
Fetus $\$$ (14 day old) & $\mathrm{n}$ & $\mathrm{n}$ & $12 \pm 4.9$ & $11 \pm 6.8$ & $20 \pm 11 \S^{b, y}$ \\
Fetus $(19$ day old) & $\mathrm{n}$ & $\mathrm{n}$ & $29 \pm 2.6^{a, d, x}$ & $\mathrm{n}$ & $91 \pm 1.0^{e}$ \\
Adult male & $\mathrm{n}$ & $\mathrm{n}$ & $\mathrm{n}$ & $\mathrm{n}$ & $94 \pm 0.9^{e}$ \\
\hline
\end{tabular}

* Mean $\pm \mathrm{SE} ; n=3-5$.

$\dagger$ Negligible, $<5 \%$.

$\$$ Fetal tissues were pooled as needed to obtain appropriate protein concentration (two to four/incubation vessel).

$\S c f$ mother: ${ }^{a} p<0.01 ;{ }^{b} p<0.001$.

cf 14-day fetus: ${ }^{d} p<0.05 ;{ }^{e} p<0.001$.

$c f$ adult male: ${ }^{x} p<0.01 ;{ }^{y} p<0.001$.

Table 2. $T_{4}$ to $r T_{3}$ monodeiodinating activity in homogenates of various tissues of maternal, fetal, and adult male rats

\begin{tabular}{|c|c|c|c|c|c|}
\hline \multirow[b]{2}{*}{ Group } & \multicolumn{5}{|c|}{ Tissue (pmol/h/mg protein) } \\
\hline & Cerebral cortex & Skin & Intestine & Skeletal muscle & Liver \\
\hline Mother & $4.5 \pm 0.90^{*}$ & $2.6 \pm 0.52 \dagger^{x}$ & $0.09 \pm 0.03$ & $0.08 \pm 0.01$ & \\
\hline Fetus (14 day old) & $19 \pm 0.49^{b, z}$ & $3.2 \pm 0.48$ & $0.72 \pm 0.17^{a, y}$ & $5.4 \pm 0.90^{b, z}$ & $1.1 \pm 0.63$ \\
\hline Fetus (19 day old) & $28 \pm 1.8^{b, d, z}$ & $2.3 \pm 0.26^{y}$ & $2.8 \pm 0.20^{b, e, z}$ & $1.7 \pm 0.25^{b, d, z}$ & \\
\hline Adult male & $7.1 \pm 1.2$ & $4.6 \pm 0.61$ & $0.08 \pm 0.02$ & $0.12 \pm 0.05$ & \\
\hline
\end{tabular}

${ }^{*}$ Mean \pm SEM $; n=3-5$. Fetal tissues were pooled as needed to obtain appropriate protein concentration ( 2-4 tissues/incubation vessel).

$\dagger c f$ mother: ${ }^{a} p<0.01 ;{ }^{b} p<0.001$.

cf 14-day fetus: ${ }^{d} p<0.01 ;{ }^{e} p<0.001$.

cf adult male: ${ }^{x} p<0.05 ;{ }^{y} p<0.01 ;{ }^{z} p<0.001$. 
$\mathrm{rT}_{3}$ in maternal skeletal muscle homogenate was too low to measure $\mathrm{Km}$ or Vmax accurately.

The $\mathrm{Km}$ and $V \max$ of $\mathrm{T}_{4} 5$-MA in fetal cerebral cortical homogenate at 14-day gestation approximated $1.1 \mu \mathrm{M}$ and 69 $\mathrm{pmol} / \mathrm{h} / \mathrm{mg}$ protein, respectively. The corresponding values of $\mathrm{Km}$ and $\mathrm{Vmax}$ in maternal cerebral cortical tissue approximated $1.6 \mu \mathrm{M}$ and $6.5 \mathrm{pmol} / \mathrm{h} / \mathrm{mg}$ protein, respectively.

The $\mathrm{Km}$ and $\mathrm{Vmax}$ of $\mathrm{T}_{4} 5$-MA in fetal intestinal homogenates measured at 19-day gestation approximated $0.48 \mu \mathrm{M}$ and 7.6 $\mathrm{pmol} / \mathrm{h} / \mathrm{mg}$ protein, respectively. The rate of $\mathrm{T}_{4}$ to $\mathrm{rT}_{3}$ conversion in maternal intestinal homogenate was too low to measure $\mathrm{Km}$ or Vmax accurately.

The kinetics of dermal $\mathrm{T}_{4}$ to $\mathrm{rT}_{3} \mathrm{MA}$ were measured in tissues of 19-day fetal and the nonpregnant adult rat. The $\mathrm{Km}$ and Vmax values were $0.21 \mu \mathrm{M}$ and $2.3 \mathrm{pmol} / \mathrm{mg}$ protein, respectively, in the fetus and $0.39 \mu \mathrm{M}$ and $6.0 \mathrm{pmol} / \mathrm{h} / \mathrm{mg}$ protein, respectively, in the adult.

\section{DISCUSSION}

Previous studies have described an increased $\mathrm{T}_{4}$ 5-MA in fetal cerebral cortex $(10,15,16)$. We support this finding and in addition, demonstrate for the first time that the $\mathrm{T}_{4} 5-\mathrm{MA}$ is markedly increased in fetal skeletal muscle (20- to 70 -fold the activity in maternal tissue) and intestine (20- to 30-fold the activity in maternal tissue). The progression of gestation from 14 to 19 days was associated with a reduction in $\mathrm{T}_{4} 5$-MA in skeletal muscle, whereas there was an increase in the activity in the case of intestine and possibly in the liver. However, the data in the case of liver in the 19-day old fetal rat (or the adult rat) were not entirely reliable as a large correction was necessary for an extensive $(>90 \%)$ degradation of the product $\left(\mathrm{rT}_{3}\right)$ even during a brief (10 min) incubation (Table 1). The fetal dermal $\mathrm{T}_{4}-5 \mathrm{MA}$ was similar to that in the mother and both these values were less than those in the nonpregnant (male) adult rat (19) (Table 2). Inasmuch as $5^{\prime}$-MA has been shown to be low in fetal tissues (8-13) and $\mathrm{rT}_{3}$ degradation is quite limited in several fetal tissues, especially at 14-day gestation, active $\mathrm{T}_{4} 5$-MA would be associated with accumulation of $\mathrm{rT}_{3}$ in fetal tissues. However, actual contribution of the various organs to fetal production of $\mathrm{rT}_{3}$ is not known. The placenta contains a very active $T_{4} 5$-monoadiodinase and is probably a major contributor to fetal $\mathrm{rT}_{3}(14)$. Our data suggest that fetal cerebral cortex, skeletal muscle, and intestine also produce $\mathrm{rT}_{3}$ and may contribute $\mathrm{rT}_{3}$ to tissues, at least locally. Similar local production of $\mathrm{rT}_{3}$ has been demonstrated in cerebral cortex of the adult rat (23).

There is ample evidence suggesting that thyroid hormones are important in fetal differentiation and development (24-28), even before development of the fetal thyroid gland (28-32). However, maternal $T_{4}$ and $T_{3}$ are poorly transported across the placenta and furthermore are degraded by a very active placental innerring deiodinase (14); thus only minute amounts of $T_{4}$ and $T_{3}$ would reach fetal tissues until the fetal thyroid becomes sufficiently productive. Because of active inner-ring and relatively inactive outer-ring deiodination, the major iodothyronine available to fetal tissues before thyroidal activity at around 17 days of gestation will be $\mathrm{rT}_{3}$ derived from metabolism of maternal $\mathrm{T}_{4}$. Some workers (33) suggest that small amounts of $T_{4}$ and $T_{3}$ contributed by the mother are physiologically relevant for the embryo and fetus in the rat. Others (34) find that even mild or moderate hyperthyroidism is harmful to the fetus. It is possible that active inner-ring deiodination serves as a measure to protect the fetus from the effects of $\mathrm{T}_{3} . \mathrm{rT}_{3}$ is known to be a potent inhibitor of the $5^{\prime} \mathrm{MA}$ of $\mathrm{T}_{4}$ to $\mathrm{T}_{3}(35)$ and has also been shown to antagonize the induction of $\mathrm{T}_{4} 5^{\prime}$-MA by insulin, cortisol, and $\mathrm{T}_{3}$ in cultured fetal mouse liver cells (36). We do not know of another biological purpose of $\mathrm{rT}_{3}$ at this time. It is possible that it plays a role in fetal differentiation or development, or both.

It is interesting to note that $\mathrm{T}_{4} 5-\mathrm{MA}$ and $\mathrm{T}_{4}$ and/or $\mathrm{rT}_{3} 5^{\prime}$ MA (i.e. degradation of $\mathrm{rT}_{3}$ ) increase during the final week of gestation in the intestine while they both decrease in skeletal muscle (Tables 1 and 2). The similarly in maturational pattern of 5'-MA and 5-MA is consistent with the notion that they may be a function of the same enzyme in several tissues as suggested in the liver (37-39). However, the magnitude of changes in $5^{\prime}$ MA and 5-MA differed suggesting that different factors regulate the two activities or that the enzymes involved are distinct. Glucocorticoids have been shown to regulate the maturation of hepatic $\mathrm{T}_{4} 5^{\prime}$-MA $(4,8,36)$. Whether glucocorticoid has a role in $\mathrm{T}_{4}$ 5-MA maturation process needs further study. The data on $\mathrm{T}_{4} 5-\mathrm{MA}$ in the various tissues suggest the possibility that the maturation of 5-MA and 5'-MA may be under local regulation and that it may change to a different degree or even a different direction among the various tissues.

Our finding of active $\mathrm{T}_{4} 5$-MA in fetal skeletal muscle and the finding of active ${ }^{125} \mathrm{I}_{-} \mathrm{T}_{4}$ uptake in sheep fetal muscle $(\sim 3$ times that of liver in ewes of 100-140 days gestation) (40) suggest that fetal muscle is active in the metabolism of thyroid hormones. It has been shown that thyroid hormone is critical in the development and growth of muscle in the chicken embryo (27). Whether $\mathrm{rT}_{3}$ contributes to this role is an interesting subject for further study.

Acknowledgments. The authors appreciate the skillful secretarial assistance of Mrs. Elena Kohn, Mrs. Donna Green, and Mrs. Judy Sirand.

\section{REFERENCES}

1. Fisher DA, Dussault JH, Sack J, Chopra IJ 1977 Ontogenesis of hypothalamopituitary-thyroid function and metabolism in man, sheep and rat. Recent Prog Horm Res 33:59-116

2. Burrow GN, Polackwich R, Donabedian R 1975 The hypothalamic-pituitarythyroid axis in normal pregnancy. In: Fisher DA, Burrow GN (eds) Perinatal Thyroid Physiology and Diseases. Raven Press, New York, pp 1-10

3. Borges M, La Bourene J, Ingbar SH 1980 Changes in hepatic iodothyronine metabolism during ontogeny of the chicken embryo. Endocrinology 107:1751-1761

4. Wu SY, Klein AH, Chopra IJ, Fisher DA 1978 Alterations in tissue thyroxine5 '-monodeiodinating activity in perinatal period. Endocrinology 103:235239

5. Fisher DA 1975 Thyroid function in the fetus. In: Fisher DA, Burrow GN (eds) Perinatal Thyroid Physiology and Disease. Raven Press, New York, pp 21-32

6. Dussault JH, Labrie F 1975 Development of hypohalamo-pituitary-thyroid axis in the neonatal rat. Endocrinology 97:1321-1324

7. Dubois JD, Dussault JH 1977 Ontogenesis of thyroid function in the neonatal rat thyroxine $\left(\mathrm{T}_{4}\right)$ and triiodothyronine $\left(\mathrm{T}_{3}\right)$ production rates. Endocrinology 101:435-441

8. Segall-Blank M, Balsam A, Ingbar SH 1981 Evidence of an altered 5'-monodeiodinase for thyroxine in the liver of fetal rabbit. Pediatr Res 15:11231127

9. Harris ARC, Fang S, Prosky J, Braverman L, Vagenaksi A 1978 Decreased outer ring monodeiodination of $T_{4}$ and reverse $T_{3}$ by the fetal and neonatal rat. Endocrinology 103:2216-222

10. Kaplan MM, Yaskoski DA 1981 Maturational patterns of iodothyronine phenolic and tyrosyl ring deiodinase activity in rat cerebrum, cerebellum and hypothalamus. J Clin Invest 67:1208-1214

11. Cheron RG, Kaplan MM, Larsen PR 1980 Divergent changes of thyroxine 5' monodeiodination in rat pituitary and liver during maturation. Endocrinology 106:1405-1409

12. Chopra IJ, Sack J, Fisher DA 1975 3,3' $5^{\prime}$ triiodothyronine (reverse $T_{3}$ ) and $3,3^{\prime} 5^{\prime}$-triiodothyronine $\left(T_{3}\right)$ in fetal and adult sheep: studies of metabolic clearance rates, production rates, serum binding and thyroidal content relative to thyroxine. Endocrinology 97:1080-1088

13. El-Zaheri MM, Braverman LE, Vagenakis AG 1980 Enhanced conversion of thyroxine to triiodothyronine by the neonatal rat pituitary. Endocrinology 106:1735-1739

14. Roti E, Braverman LE, Fang SL, Alex S, Emerson CH 1980 Ontogenesis of placental inner ring thyroxine deiodinase and amniotic fluid $3,3^{\prime} 5^{\prime}$-triiodothyronine concentration in the rat. Endocrinology 111:959-963

15. Huang TS, Beredo A, Solomon DH, Chopra IJ 1986 The inner ring (5-) monodeiodination of thyroxine $\left(\mathrm{T}_{4}\right)$ in cerebral cortex during fetal neonatal and adult life. Metabolism 35:272-277

16. Tanaka K, Inada M, Ishii H, Naito K, Nishikawa M, Mashio Y, Imura H 1981 Inner ring monodeiodination of thyroxine and 3,5,3'-L triiodothyronine in rat brain. Endocrinology 109:1619-1624

17. Chopra IJ, Sack J, Fisher DA 1975 Reverse $T_{3}$ in the fetus and newborn. In: Fisher DA, Burrow GN (eds) Perinatal Thyroid Physiology and Disease. Raven Press, New York, pp 33-48 
18. Chopra IJ 1974 A radioimmunoassay for measurement of $3,3^{\prime} 5^{\prime}$-triiodothyronine. J Clin Invest 54:583-592

19. Huang TS, Chopra IJ, Beredo A, Solomon DH, Chua Teco GN 1985 Skin is an active site for the inner ring monodeiodination of thyroxine to $3,3^{\prime} 5^{\prime}$ triiodothyronine. Endocrinology 117:2106-2113

20. Bradford MM $1976 \mathrm{~A}$ rapid and sensitive method for the quantification of microgram quantities of protein utilizing the principle of protein-dye binding. Anal Biochem 72:248-274

21. Lineweaver H, Burk D 1934 The determination of enzyme dissociation constants. J Am Chem Soc 56:658-662

22. Glantz SA 1981 Primer of Biostatistics. McGraw-Hill Book Co., New York, pp 30-93

23. Obregon MJ, Larsen PR, Silva JE 1985 Plasma Kinetics, tissue distribution and cerebrocortical sources of reverse triiodothyronine in the rat. Endocrinology 116:2192-2200

24. Brasel JA, Boyd DB 1975 Influence of thyroid hormone on fetal brain growth and development. In: Fisher DA, Burrow GN (eds) Perinatal Thyroid Physiology and Disease. Raven Press, New York, pp 59-71

25. Fisher DA, Hoath S, Lakshmanan J 1982 The thyroid hormone effects on growth and development may be mediated by growth factors. Endocrinol Exp (Bratisl) 16:259-271

26. Timiras PS, Cons JM 1982 Hormone during prenatal and neonatal development. In: Vernadakis A, Timiras PS (eds) Hormones in Development and Aging. SP Medical and Scientific Books, New York

27. King DB, King CR 1978 Muscle growth and development in chick embryo: Thyroidal influence on ribosomal RNA metabolism. Gen Comp Endocrinol 34:234-242

28. Hitchcock KR 1979 Hormones and the lung. I. Thyroid hormones and glucocorticoids in lung development. Anat Rec 194:15-23

29. Ekins R, P Edwards, B Newman 1982 The role of Binding-proteins in hormone delivery. In: Albertini A, Ekin RP (eds) Free Hormones in Blood. Elsevier Biomedical Press, New York, pp 3-43

30. Sweney LR, Shapiro BL 1975 Thyroxine and palatal development in rat embryos. Dev Biol 42:19-27

31. Woods RJ, Sinha AK, Ekins RP 1984 Uptake and metabolism of thyroid hormones by the rat fetus in early pregnancy. Clin Sci 67:359-363

32. Obregon MJ, Mallol J, Pastor R, Morreale De Escobar G, Escobar Del Rey F $1984 \mathrm{~L}$-Thyroxine and 3,5,3' -triiodo-L-thyronine in rat embryos before onset of fetal thyroid function. Endocrinology 114:305-307

33. Morreale de Escobar G, Pastor R, Obregon MJ, Escobar del Rey F 1986 Effects of maternal thyroidectomy $(T)$ on rat embryonic $T_{4}$ and $T_{3}$ contents and development, before and after onset of fetal thyroid function (FTF). In: Medeiros-Neto G, Gaitan E (eds) Frontiers in Thyroidology. Plenum Medical Book Company, New York, pp 1177-1181

34. Lakshmanan J, Alm J, Beri U, Fisher DA 1984 On the mechanisms of growth retardation caused by neonatal hyperthyroidism. 60th Annual Meeting of the American Thyroid Association, September 19-22, p T-35(abstr 70)

35. Chopra IJ 1977 A study of extrathyroidal conversion of thyroxine $\left(T_{4}\right)$ to 3,5,3'-triiodothyronine $\left(\mathrm{T}_{3}\right)$ in vitro. Endocrinology 101:453-463

36. Han DC, Sato K, Fujii Y, Tsushima T, Shizume K 1986 3,3',5'-triiodothyronine inhibits iodothyronine $5^{\prime}$-deiodinating activity induced by $3,5,3^{\prime}$-triiodothyronine at equimolar concentrations in cultured fetal mouse liver. Endocrinology 119:1076-1082

37. Chopra IJ Chua Teco GN 1982 Characteristics of inner ring (3 or 5) monodeiodination of 3,5-diiodothyronine in rat liver-evidence suggesting marked similarities of inner and outer ring deiodinase for iodothyronine. Endocrinology 110:89-97

38. Hesch RD Kohrle J 1986 Intracellular pathways of iodothyronine metabolism. In: Inghar SH, Braverman LE (eds) The Thyroid, A Fundamental and Clinical Text, 5th ed. J. B. Lippincott Co., Philadelphia, pp 154-247

39. Fekkes D, Henneman G, Visser TJ 1982 Evidence for a single enzyme in rat liver catalzing the deiodination of the tyrosyl and the phenolie ring of iodothyronines. Bichem J 201:673-676

40. Sack J, Fisher DA 1975 Thyroid hormone metabolism in amniotic fluid of man and sheep. In: Fisher DA, Burrow GN (eds) Perinatal Thyroid Physiology and Diseases. Raven Press, New York, pp 49-58 